\title{
PERBEDAAN KEMAMPUAN KOMUNIKASI MATEMATIS SISWA YANG DIAJAR DENGAN MENGGUNAKAN MODEL PEMBELAJARAN KOOPERATIF TIPE THINK PAIR SHARE DENGAN TIPE THINK TALK WRITE PADA MATERI KUBUS DAN BALOK DI KELAS VIII SMPN 27 MEDAN
}

\author{
Nova Alwi Sihombing, Amin Fauzi \\ ${ }^{l}$ FMIPA, UNIMED Meda, Indonesia \\ E-mail: alwi.sihombing@yahoo.com
}

\begin{abstract}
ABSTRAK
Penelitian ini bertujuan untuk mengetahui apakah kemampuan komunikasi matematis siswa yang diajar dengan model pembelajaran kooperatif tipe Think Talk Write (TTW) lebih tinggi daripada kemampuan komunikasi matematis siswa yang diajar dengan model pembelajaran kooperatif tipe Think Pair Share (TPS) pada pokok bahasan kubus dan balok di kelas VIII. Jenis penelitian ini adalah eksperimen. Populasi dalam penelitian ini adalah seluruh siswa kelas VIII SMP N 27 Medan semester genap, yang terdiri dari 9 kelas. Sampel dalam penelitian ini adalah dua kelas yang dipilih secara acak dimana kelas VIII-2 sebagai kelas eksperimen TTW dan kelas VIII-3 sebagai kelas eksperimen TPS dengan masing-masing jumlah sampel 40 orang dalam tiap kelas. Penelitian ini menggunakan satu jenis instrumen yaitu post-test dalam bentuk essay. Dari hasil penelitian yang diberikan, diperoleh nilai rata-rata post-test kelas eksperimen TTW sebesar 70,3125 dan kelas eksperimen TPS memperoleh nilai rata-rata 64,6875. Berdasarkan pengujian hipotesis yaitu dengan mengggunakan uji $t$ dengan $\alpha=0,05$ diperoleh $t_{\text {hitung }}<t_{\text {tabel }}(1,5857<1,667)$. Hal ini menunjukkan bahwa $H_{0}$ diterima dan $H_{a}$ ditolak sehingga dapat dinyatakan kemampuan komunikasi matematis siswa yang diajar dengan menggunakan model pembelajaran kooperatif tipe TTW lebih tinggi daripada kemampuan komunikasi matematis siswa yang diajar dengan menggunakan model pembelajaran kooperatif tipe TPS.
\end{abstract}

Kata kunci: Komunikasi matematis, TPS, TTW

\section{ABSTRACT}

This research aims to know determine whether the mathematical communication ability of students who learn with Think Talk Write (TTW) cooperative learning model is higher than mathematical communication ability of students who learn with Think Pair Share (TPS) cooperative learning model on the material of the cube and the beam grade VIII. Type of this research $s$ using quasi experiment. Population in this research is all student grade VIII SMP N 27 Medan., consists of 9 classes. The sampling in this research was done by random sampling, VIII-2 is called experimental class TTW and VIII-3 is called experiment class TPS which amounts to 40 students per class. The instrument used in this research is post-test only design. From the research conducted, obtained the average value of post-test experimental class TTW amounts 70,3125 and the average value of

Nova Alwi Sihombing, Amin Fauzi. Perbedaan Kemampuan Komunikasi Matematis Siswa yang Diajar dengan Menggunakan Model Pembelajaran Kooperatif Tipe Think Pair Share dengan Tipe Think Talk Write pada Materi Kubus dan Balok di Kelas VIII SMPN 27 Medan. Jurnal Inspiratif, Vol. 3 No. 2 Agustus 2017 
post-test experimental class TPS amounts 64,6875. Based on hypothesis testing by using $t$ test with $\alpha=0,05$ obtained $t_{\text {hitung }}<t_{\text {tabel }}(1,5857<1,667)$. This shows that $H_{o}$ accepted and $H_{a}$ rejected so that it can be stated that the mathematical communication ability of students who learn with Think Talk Write (TTW) cooperative learning model is higher than mathematical communication ability of students who learn with Think Pair Share (TPS) cooperative learning model

\section{Keywords : Mathematical communication TPS, TTW}

\section{Pendahuluan}

Matematika merupakan salah satu ilmu universal yang sangat penting dalam berbagai disiplin ilmu serta berperan dalam pengembangan ilmu pengetahuan dan teknologi. Matematika berperan sebagai bahasa simbolik dalam dunia keilmuan sehingga memungkinkan terwujudnya komunikasi secara cermat dan tepat. Sehingga dapat dikatakan matematika berperan penting dalam perkembangan di bidang teknologi dan komunikasi.

Matematika sebagai ilmu yang sangat penting harusnya menjadi pelajaran yang disenangi oleh siswa yang sedang mempelajarinya. Bukan sebaliknya, pelajaran matematika sering menjadi momok bagi siswa pada umumnya. Kenyataan yang ada menunjukkan hasil belajar siswa pada bidang studi matematika kurang menggembirakan. Seperti yang diungkapkan Reskiwati (2014:231) bahwa : "Kegiatan pembelajaran matematika di sekolahsekolah sampai saat ini belum memperlihatkan hasil yang memuaskan."

Salah satu faktor yang mempengaruhi rendahnya hasil belajar matematika adalah siswa menganggap matematika pelajaran yang sangat sulit dan cenderung tidak disukai siswa sebagaimana yang diungkapkan Abdurrahman (2012:208) bahwa : "Dari berbagai bidang studi yang diajarkan disekolah, matematika merupakan bidang studi yang dianggap paling sulit oleh para siswa, baik yang berkesulitan belajar dan lebih-lebih bagi siswa yang berkesulitan belajar." Surya (2010) menyatakan bahwa pada dasarnya siswa sangat membutuhkan pembelajaran yang menarik, inovatif, dan menyenangkan. Guru dapat berimprovisasi. Kesulitan yang dialami siswa dalam belajar matematika dan rendahnya hasil yang diperoleh dapat disebabkan karena metode pembelajaran tidak sesuai dengan materi ajar dan kemampuan peserta didik. Pembelajaran yang memaksimalkan pemikiran siswa dapat membangun karakter positif.

Darkasyi (2014:22) menyatakan bahwa : "Rendahnya hasil belajar matematika bukan hanya disebabkan karena matematika yang sulit, melainkan disebabkan oleh beberapa faktor yang meliputi siswa itu sendiri, guru, pendekatan pembelajaran, maupun lingkungan belajar yang saling berhubungan satu sama lain. Faktor dari siswa itu sendiri adalah kurangnya pemahaman konsep siswa terhadap materi yang diajarkan. Selain itu, faktor lain yang dapat mempengaruhi rendahnya hasil belajar siswa adalah adanya anggapan/asumsi yang keliru dari guruguru yang menganggap bahwa pengetahuan itu dapat dipindahkan secara utuh dari pikiran guru ke pikiran siswa."

Salah satu standar proses yang harus dikuasai siswa adalah komunikasi matematis. Kemampuan komunikasi matematis siswa sangat perlu untuk ditingkatkan, karena melalui komunikasi matematis siswa dapat melakukan organisasi berpikir matematisnya baik secara lisan ataupun tulisan, siswa bisa memberi respon dengan tepat, baik di antara siswa itu sendiri maupun antara siswa dengan guru selama proses pembelajaran berlangsung. Suhaedi (2012:191) menyatakan : "Siswa yang memiliki kemampuan komunikasi yang

Nova Alwi Sihombing, Amin Fauzi. Perbedaan Kemampuan Komunikasi Matematis Siswa yang Diajar dengan Menggunakan Model Pembelajaran Kooperatif Tipe Think Pair Share dengan Tipe Think Talk Write pada Materi Kubus dan Balok di Kelas VIII SMPN 27 Medan. Jurnal Inspiratif, Vol. 3 No. 2 Agustus 2017 
baik, cenderung dapat membuat berbagai representasi yang beragam, sehingga lebih memudahkan siswa dalam mendapatkan alternatif-alternatif penyelesaian berbagai permasalahan matematis."

Sebagaimana yang diungkapkan Susanto (2015:170) di dalam International Journal of Education and Research : "Rendahnya aktivitas komunikasi matematis siswa baik lisan maupun tulisan, mengakibatkan sebagian besar siswa mengalami kesulitan dalam komunikasi matematis, seperti : (1) kurangnya keberanian siswa dalam bertanya, ditunjukkan dengan kebanyakan siswa membiarkan guru terus menjelaskan materi tanpa mengajukan pertanyaan, (2) kurangnya keberanian siswa dalam mengajukan pendapat/ide, dilihat dari pernyataan siswa yang masih ragu-ragu dalam menjawab pertanyaan guru, (3) rendahnya kemampuan siswa dalam membuat garis besar atau kesimpulan tentang materi yang dipelajari, dan (4) siswa tidak berani untuk menunjukkan pekerjaan mereka, hal ini dilihat dari sedikitnya siswa yang bersedia untuk menyajikan hasil kerja mereka di depan kelas."

Menurut Nartani (2015:284) di dalam International Journal of Innovation and Research in Educational Sciences : "Realita yang ada dilapangan menunjukkan bahwa keterbatasan pengetahuan guru dan kebiasaan belajar siswa dikelas yang dilakukan dengan cara konvensional, hal ini tidak dapat meningkatkan kemampuan komunikasi matematis siswa secara optimal. Penyajian yang sering dilakukan guru dikelas yaitu : (1) pertama, mengajar tentang teori, (2) memberikan contoh soal, (3) memberikan latihan."

Salah satu langkah yang bisa dilakukan oleh guru adalah memilih model pembelajaran yang tepat, salah satunya adalah model pembelajaran kooperatif. Menurut Ansari (2016 : 84) bahwa : "Pembelajaran kooperatif merupakan pembelajaran yang mengutamakan kerjasama di antara siswa untuk mencapai tujuan pembelajaran. Pembelajaran kooperatif dapat menciptakan saling ketergantungan antar siswa, sehingga sumber belajar bagi siswa bukan hanya guru dan buku tetapi juga sesama siswa."

Think Pair Share merupakan jenis pembelajaran koopertatif yang dirancang untuk memengaruhi pola interaksi siswa (Trianto, 2009:81). Menurut Ansari (2016:92) : "Model pembelajaran diskusi kelas dengan strategi Think Pair Share atau "saling bertukar pikiran secara berpasangan", merupakan struktur pembelajaran kooperatif yang dapat meningkatkan partisipasi siswa dan relatif mudah diterapkan di kelas. Selain itu, strategi ini juga merupakan cara yang efektif untuk meningkatkan daya pikir siswa."

Think Pair Share adalah strategi diskusi kooperatif yang dikembangkan oleh Frank Lyman dan koleganya dari Universitas Maryland pada tahun 1981. Think Pair Share memiliki prosedur yang secara eksplisit memberi siswa waktu untuk berpikir, menjawab, saling membantu satu sama lain. Dengan demikian, diharapkan siswa mampu bekerja sama, saling membutuhkan, dan saling bergantung pada kelompok kecil secara kooperatif (Shoimin, 2016:209).

Strategi pembelajaran Think Talk Write pada dasarnya dibangun melalui berpikir, berbicara, dan menulis. Alur kemajuan strategi Think Talk Write dimulai dari keterlibatan siswa dalam berpikir atau berdialog dengan dirinya sendiri setelah proses membaca, selanjutnya berbicara dan membagi ide (sharing) dengan temannya sebelum menulis. Suasana seperti ini lebih efektif jika dilakukan dalam kelompok heterogen dengan 3-5 siswa. Dalam kelompok ini siswa diminta membaca, membuat catatan kecil, menjelaskan, mendengar dan membagi ide bersama teman kemudian mengungkapkannya melalui tulisan (Ansari, 2016:100).

Nova Alwi Sihombing, Amin Fauzi. Perbedaan Kemampuan Komunikasi Matematis Siswa yang Diajar dengan Menggunakan Model Pembelajaran Kooperatif Tipe Think Pair Share dengan Tipe Think Talk Write pada Materi Kubus dan Balok di Kelas VIII SMPN 27 Medan. Jurnal Inspiratif, Vol. 3 No. 2 Agustus 2017 


\section{Metode}

Untuk menjawab permasalahan di atas telah dilakukan penelitian kuasi eksperimen. Populasi dalam penelitian ini adalah seluruh kelas VIII SMP Negeri 27 Medan. Cara pengambilan sampel yaitu dengan random sampling, dengan kelas VIII-2 sebagai kelas eksperimen I menggunakan TTW dan kelas VIII-3 sebagai kelas eksperimen II menggunakan

\section{Tabel 1. Desain Penelitian}

\begin{tabular}{|l|c|c|}
\hline Kelas & Perlakuan & $\begin{array}{c}\text { Pengukuran } \\
\text { Posttest }\end{array}$ \\
\hline Eksperimen I & $\mathrm{X}_{1}$ & $\mathrm{~T}_{\text {(eks 1) }}$ \\
\hline Eksperimen II & $\mathrm{X}_{2}$ & $\mathrm{~T}_{\text {(eks 2) }}$ \\
\hline $\mathrm{X}_{1} \quad$ : Pembelajaran kooperatif tipe \\
\multicolumn{2}{|c|}{ Think Talk Write (TTW) } \\
$\mathrm{X}_{2} \quad$ : Pembelajaran kooperatif tipe \\
\multicolumn{3}{|c|}{ Think Pair Share (TPS) } \\
$\mathrm{T}_{\text {(eks 1 }} \quad$ : Tes akhir kelas eksperimen I \\
$\mathrm{T}_{\text {(eks 2) }} \quad$ : Tes akhir kelas eksperimen II
\end{tabular}

Prosedur penelitian yang dilakukan terdiri dari (1) tahap persiapan; (2) tahap pelaksanaan; (3) tahap penyelesaian. Adapun langkah yang sudah dipersiapakan sampai pada saat pelaksanaan penelitian
TPS. Untuk mengetahui kemampuan komunikasi matematis siswa yang diperoleh dari penerapan perlakuan tersebut, maka siswa diberikan tes dalam bentuk essay test mencakup materi kubus dan balok. Adapun bentuk desain yang digunakan adalah Posttest Only Control Group Design. Berikut ini rancangan penelitian yang akan dilakukan (menurut Sugiyono, 2016:112), yaitu:

yaitu; menetapkan sekolah dan observasi, mengumpulkan data, menetapkan jadwal, mengurus surat izin, menentukan kelas sampel, mempersiapkan perangkat pembelajaran, soal tes akhir berupa soal essay yang sebelumnya sudah divalidasi.

\section{Hasil dan Pembahasan}

Dari hasil pemberian post-test diperoleh nilai rata-rata hasil kemampuan komunikasi matematis pada kelas I (TTW) adalah 70,3125 dan nilai rata-rata pada kelas II (TPS) adalah 64,6875. Rekapitulasi hasil post-test pada kelas eksperimen I (TTW) berjumlah 40 orang dapat dilihat pada tabel berikut :

Tabel 2 Rekapitulasi Hasil Post-TestKelas Eksperimen TTW

\begin{tabular}{|c|c|c|c|c|c|c|}
\cline { 2 - 6 } \multicolumn{1}{c|}{} & \multicolumn{2}{c|}{ Nomor 1 } & Nomor 2 & Nomor 3 & Nomor 4 & Nilai \\
\hline Jumlah & 115 & 115 & 116 & 104 & 2812,5 \\
\hline Maks & 4 & 4 & 4 & 4 & 93,75 \\
\hline Min & 1 & 1 & 1 & 0 & 50 \\
\hline $\begin{array}{c}\text { Rata- } \\
\text { Rata }\end{array}$ & 2,8750 & 2,8750 & 2,9000 & 2,6000 & 70,3125 \\
\hline Varians & 1,0353 & 1,0353 & 1,0154 & 1,5795 & 197,8165 \\
\hline $\begin{array}{c}\text { Simp. } \\
\text { Baku }\end{array}$ & 1,0175 & 1,0175 & 1,0077 & 1,2568 & 14,0647 \\
\hline
\end{tabular}

Berdasarkan tabel 2. diatas, rata-rata skor untuk nomor 1 dan nomor 2 sama yaitu 2,8750 , sedangkan rata-rata soal nomor 3 adalah 2,9000 dan rata-rata soal nomor 4 adalah 2,600. Dari keempat soal, rata-rata skor soal nomor 3 pada aspek menjelaskan tampak lebih unggul dan ratarata skor soal nomor 4 pada aspek ekspresi matematika lebih rendah.

Nova Alwi Sihombing, Amin Fauzi. Perbedaan Kemampuan Komunikasi Matematis Siswa yang Diajar dengan Menggunakan Model Pembelajaran Kooperatif Tipe Think Pair Share dengan Tipe Think Talk Write pada Materi Kubus dan Balok di Kelas VIII SMPN 27 Medan. Jurnal Inspiratif, Vol. 3 No. 2 Agustus 2017 
Tabel 3. Rekapitulasi Hasil Post-Test Kelas Eksperimen TPS

\begin{tabular}{|c|c|c|c|c|c|}
\cline { 2 - 6 } \multicolumn{1}{c|}{} & Nomor 1 & Nomor 2 & Nomor 3 & Nomor 4 & Nilai \\
\hline Jumlah & 111 & 113 & 101 & 89 & 2587,5 \\
\hline Maks & 4 & 4 & 4 & 4 & 93,75 \\
\hline Min & 1 & 1 & 0 & 0 & 31,25 \\
\hline $\begin{array}{c}\text { Rata- } \\
\text { Rata }\end{array}$ & 2,7750 & 2,8250 & 2,5250 & 2,2250 & 64,6875 \\
\hline Varians & 1,1532 & 1,1224 & 1,1788 & 2,0250 & 305,5889 \\
\hline Simp. Baku & 1,0739 & 1,0595 & 1,0857 & 1,4230 & 17,4811 \\
\hline
\end{tabular}

Berdasarkan tabel 3.2. diatas, ratarata skor untuk soal nomor 1 sampai soal nomor 4 relatif berbeda. Rata-rata skor untuk soal nomor 1 yaitu 2,7750 , rata-rata skor soal nomor 2 yaitu 2,8250 , rata-rata skor soal nomor 3 yaitu 2,5250, dan ratarata skor soal nomor 4 yaitu 2,2250. Dari

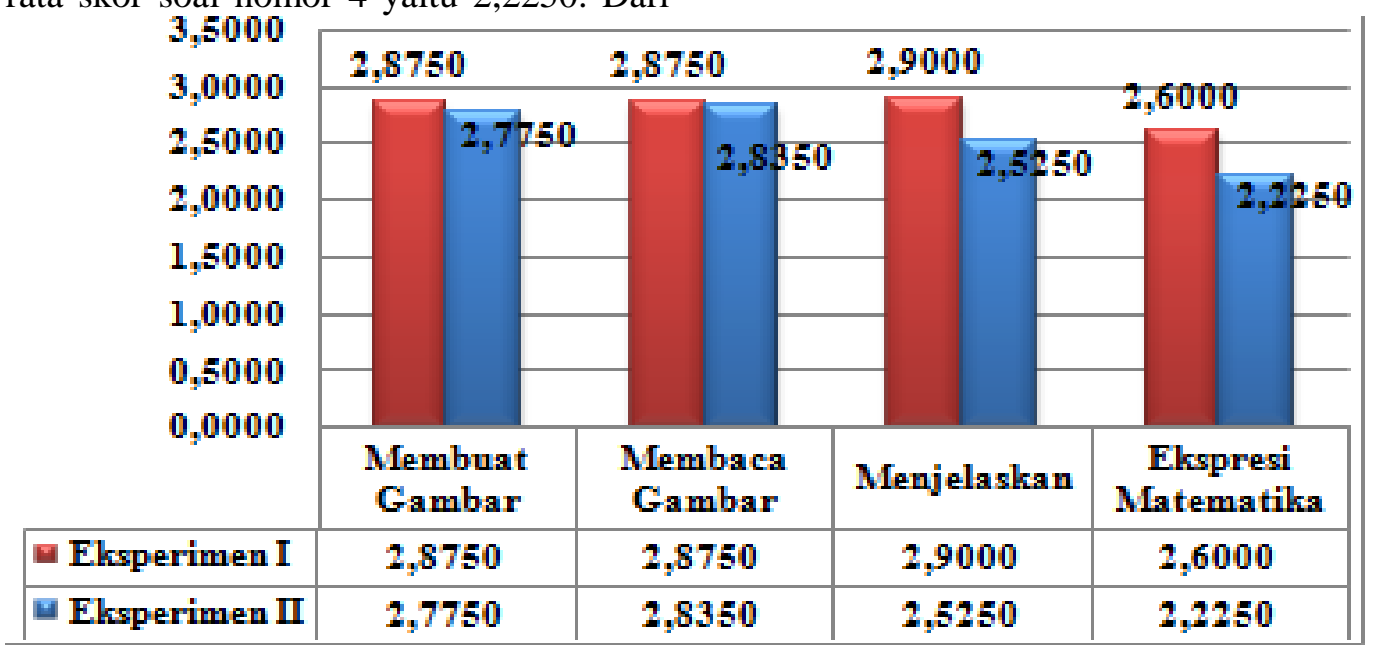

Gambar 1. Perbandingan Skor Rata-Rata Posttest Kelas Eksperimen TTW dan Kelas Eksperimen TPS

Data diatas selanjutnya akan digunakan sebagai landasan untuk melakukan uji statistik.

\section{A. Uji Normalitas Data}

Uji normalitas dilakukan untuk mengetahui apakah sampel data berasal

$$
\alpha=0,05 \text {. }
$$

keempat soal rata-rata skor soal nomor 2 pada aspek membaca gambar tampak lebih unggul dan rata-rata skor soal nomor 4 pada aspek ekspresi matematika lebih rendah. 
Tabel 4. Hasil Analisis Normalitas Posttest

\begin{tabular}{|c|c|c|c|c|c|c|c|}
\hline \multirow[t]{2}{*}{ พุo } & \multirow{2}{*}{$\begin{array}{c}\text { Aspek Komunikasi } \\
\text { Matematis }\end{array}$} & \multicolumn{2}{|c|}{$\begin{array}{c}\text { Eksperimen I } \\
\text { (TTW) }\end{array}$} & \multirow[t]{2}{*}{ Keterangan } & \multicolumn{2}{|c|}{$\begin{array}{c}\text { Eksperimen II } \\
\text { (TPS) }\end{array}$} & \multirow[t]{2}{*}{ Keterangan } \\
\hline & & $\mid \mathrm{L}_{\text {bitumg }}$ & $\mathrm{L}_{\text {tabd }}$ & & $\mathrm{L}_{\text {hitans }}$ & $\mathrm{L}_{\text {tabel }}$ & \\
\hline 1 & Membuat Gambar & 0,1301 & \multirow{5}{*}{$=$} & Normal & 0,1292 & \multirow{5}{*}{ E } & Normal \\
\hline 2 & Membaca Gambar & 0,1301 & & Normal & 0,1335 & & Normal \\
\hline 3 & Menjelaskan & 0,1379 & & Normal & 0,1300 & & Normal \\
\hline 4 & $\begin{array}{l}\text { Eksperesi } \\
\text { Matematis }\end{array}$ & 0,1335 & & Normal & 0,1301 & & Normal \\
\hline 5 & Nilai Total & 0,1188 & & Normal & 0,0849 & & Normal \\
\hline
\end{tabular}

Dari tabel 4. terlihat bahwa $\mathrm{L}_{\text {hitung }}<\mathrm{L}_{\text {tabel }} \mathrm{l}$ pada taraf nyata $\alpha=0,05$. Dengan demikian dapat disimpulkan bahwa distribusi posttest pada kedua kelas adalah normal.
Pengujian homogenitas data dilakukan dengan menggunakan uji $\mathrm{F}$ pada data posttest dengan rumus sebagai berikut

$$
F_{\text {hitung }}=\frac{\text { variansterbesar }}{\text { variansterkecil }}
$$

\section{B. Uji Homogenitas Data}

Tabel 5. Hasil Analisis Homogenitas Data Penelitian

\begin{tabular}{|l|c|c|c|c|c|}
\hline \multirow{2}{*}{$\begin{array}{c}\text { Aspek Komunikasi } \\
\text { Matematis }\end{array}$} & \multicolumn{2}{|c|}{ Varians } & \multirow{2}{*}{$\mathrm{F}_{\text {litumg }} \mathrm{F}_{\text {tabel }}$} & \multirow{2}{*}{ Keterangan } \\
\cline { 2 - 3 } & Eks l & Eks 2 & & & \\
\hline Membuat Gambar & 1,0353 & 1,1532 & 1,1139 & & Homogen \\
\hline Membaca Gambar & 1,0353 & 1,1224 & 1,0841 & \multirow{4}{*}{1.7045} & Homogen \\
\hline Menjelaskan & 1,0154 & 1,1788 & 1,1609 & Homogen \\
\hline Eksperisi Matematika & 1,5795 & 2,0250 & 1,2821 & & Homogen \\
\hline Nilai Total & 197,8165 & 305,5889 & 1,5448 & & Homogen \\
\hline
\end{tabular}

Pada Tabel 5 diatas terlihat bahwa pada post-tes, harga $F_{\text {hitung }}<F_{\text {tabel }}$ artinya setiap sampel mempunyai varians yang sama.

Berdasarkan tabel 3.3. dan tabel 3.4. dapat disimpulkan bahwa telah memenuhi syarat untuk dilakukan uji beda rata-rata dengan uji-t.

\section{Uji Hipotesis Data} adalah :
Hipotesis yang diuji untuk Posttest

$$
\begin{array}{ll}
H_{o}: & \mu_{1} \leq \mu_{2} \\
H_{a}: & \mu_{1}>\mu_{2}
\end{array}
$$

Pengujian hipotesis ini dilakukan dengan uji-t satu arah yaitu pihak kanan, dengan kriteria yaitu terima $\mathrm{H}_{0}$ jika $\mathrm{t}_{\text {hitung }}<$ $\mathrm{t}_{\text {tabel }}$. Dimana didapat dari daftar distribusi $\mathrm{t}$ dengan $\mathrm{dk}=\left(n_{1}+n_{2}-2\right)$ pada taraf signifikan $\alpha=0,05$, untuk harga t lainnya $\mathrm{H}_{0}$ ditolak.

Nova Alwi Sihombing, Amin Fauzi. Perbedaan Kemampuan Komunikasi Matematis Siswa yang Diajar dengan Menggunakan Model Pembelajaran Kooperatif Tipe Think Pair Share dengan Tipe Think Talk Write pada Materi Kubus dan Balok di Kelas VIII SMPN 27 Medan. Jurnal Inspiratif, Vol. 3 No. 2 Agustus 2017 
Tabel 6. Ringkasan Perhitungan Uji Hipotesis

\begin{tabular}{|c|c|c|c|}
\hline \multicolumn{2}{|c|}{ Rata-rata } & \multirow{2}{*}{$\mathrm{t}_{\text {hitung }}$} & \multirow{2}{*}{$\mathrm{t}_{\text {tabel }}$} \\
\cline { 1 - 2 } TTW & TPS & & \\
\hline 70.3125 & 64,6875 & 1,5857 & 1,667 \\
\hline
\end{tabular}

komunikasi matematis siswa yang diajar

Dari data post-test diatas diperoleh dengan menggunakan model pembelajaran bahwa $t_{\text {hitung }}<+t_{1-\alpha}$ yaitu 1,5857 $<1,667$ pada taraf $\alpha=0,05$ dan $\mathrm{dk}=40+40-2$ $=78$. Yang berati bahwa $\mathrm{H}_{0}$ diterima dan $\mathrm{H}_{\mathrm{a}}$ ditolak, sehingga pada post-test dapat kooperatif tipe TTW lebih tinggi daripada kemampuan komunikasi matematis siswa yang diajar dengan menggunakan model pembelajaran kooperatif tipe TPS. disimpulkan bahwa kemampuan

Tabel 7. Uji Hipotesis Post-Test Tiap Aspek Kemampuan Komunikasi Matematis

\begin{tabular}{|c|c|c|c|c|c|c|}
\hline \multirow{2}{*}{ No } & \multirow{2}{*}{ Aspek } & \multicolumn{2}{|c|}{ Rata-Rata } & \multirow{2}{*}{$t_{\text {thitugg }}$} & \multirow{2}{*}{$t_{t a b e l}$} & \multirow{2}{*}{ Ket } \\
\hline & & Eks 1 & Eks 2 & & & \\
\hline 1 & $\begin{array}{l}\text { Membuat } \\
\text { Gambar }\end{array}$ & 2,8750 & 2,7750 & 0,4275 & \multirow{4}{*}{1,667} & $\begin{array}{c}\mathrm{H}_{0} \\
\text { diterima }\end{array}$ \\
\hline 2 & $\begin{array}{l}\text { Membaca } \\
\text { Gambar }\end{array}$ & 2,8750 & 2,8250 & 0,2152 & & $\begin{array}{c}\mathrm{H}_{0} \\
\text { diterima }\end{array}$ \\
\hline 3 & Menjelaskan & 2,9000 & 2,5250 & 1,6012 & & $\begin{array}{c}\mathrm{H}_{0} \\
\text { diterima }\end{array}$ \\
\hline 4 & $\begin{array}{l}\text { Ekspresi } \\
\text { Matematika }\end{array}$ & 2,6000 & 2,2250 & 1,2492 & & $\begin{array}{c}\mathrm{H}_{0} \\
\text { diterima }\end{array}$ \\
\hline
\end{tabular}

Untuk memperkuat hasil penelitian ini , peneliti membandingkan hasil penelitian yang diperoleh dengan hasil penelitian terdahulu yang relevan dengan penelitian ini yaitu hasil penelitian yang dilakukan oleh Fertilia (2014), dengan judul "Perbandingan kemampuan representasi matematis siswa antara model pembelajaran TTW dan TPS". Berdasarkan hasil penelitian diperoleh (menggunakan TTW) adalah 78,77 dan nilai rata-rata sampel kelas eksperimen 2 (menggunakan TPS) adalah 65,18. Hal ini menandakan bahwa kemampuan representasi matematis siswa dengan model pembelajaran TTW lebih tinggi daripada kemampuan representasi matematis siswa dengan model pembelajaran TPS rata-rata sampel kelas eksperimen 1

Tabel 8. Kategori Penilaian Kemampuan Komunikasi Matematis

\begin{tabular}{|c|c|}
\hline Skor & Kategori \\
\hline$S R<0,50$ & Sangat Kurang \\
\hline $0,50 \leq S R<1,50$ & Kurang \\
\hline $1,50 \leq S R<2,50$ & Cukup \\
\hline $2,50 \leq S R<3,50$ & Baik \\
\hline$S R \geq 3,50$ & Sangat Baik \\
\hline
\end{tabular}

Nova Alwi Sihombing, Amin Fauzi. Perbedaan Kemampuan Komunikasi Matematis Siswa yang Diajar dengan Menggunakan Model Pembelajaran Kooperatif Tipe Think Pair Share dengan Tipe Think Talk Write pada Materi Kubus dan Balok di Kelas VIII SMPN 27 Medan. Jurnal Inspiratif, Vol. 3 No. 2 Agustus 2017 
Tingkat kemampuan komunikasi matematis siswa yang diajar dengan model pembelajaran kooperatif tipe TPS pada pokok bahasan Kubus dan Balok di kelas VIII SMP N 27 Medan kategori cukup. Rata-rata skor dalam masing-masing aspek sebagai berikut : (1) Pada aspek membuat gambar diperoleh rata-rata skor yaitu 2,7750. Sesuai dengan tabel kategori penilaian kemampuan komunikasi matematis siswa, menunjukkan bahwa pada soal nomor satu dalam kategori baik. (2) Pada aspek membaca gambar diperoleh rata-rata skor yaitu 2,8250. Sesuai dengan tabel kategori penilaian kemampuan komunikasi matematis siswa, menunjukkan bahwa pada soal nomor 2 dalam kategori baik. (3) Pada aspek menjelaskan diperoleh rata-rata skor yaitu 2,5250. Sesuai dengan tabel kategori penilaian kemampuan komunikasi matematis siswa, menunjukkan bahwa pada soal nomor 3 dalam kategori baik. (4) Sedangkan pada aspek ekspresi matematika rata-rata skor yaitu 2,2250. Sesuai dengan tabel kategori penilaian kemampuan komunikasi matematis siswa, kemampuan menyatakan ide matematika ke dalam simbol matematika begitu juga dengan perhitungannya dalam kategori cukup.

Sedangkan tingkat kemampuan komunikasi matematis siswa yang diajar dengan model pembelajaran kooperatif tipe TTW pada pokok bahasan Kubus dan Balok di kelas VIII SMP N 27 Medan kategori baik. Rata-rata skor dalam masing-masing aspek sebagai berikut : (1) Pada aspek membuat gambar diperoleh rata-rata skor yaitu 2,8750. Sesuai dengan tabel kategori penilaian kemampuan komunikasi matematis siswa, menunjukkan bahwa pada soal nomor satu dalam kategori baik. (2) Pada aspek membaca gambar diperoleh rata-rata skor yaitu 2,8750. Sesuai dengan tabel kategori penilaian kemampuan komunikasi matematis siswa, menunjukkan bahwa pada soal nomor 2 dalam kategori baik. (3) Pada aspek menjelaskan diperoleh rata-rata skor yaitu 2,9000. Sesuai dengan tabel kategori penilaian kemampuan komunikasi matematis siswa, pada soal nomor 3 dalam kategori baik. (4) Dan pada aspek ekspresi matematika diperoleh rata-rata skor yaitu 2,6000. Sesuai dengan tabel kategori penilaian kemampuan komunikasi matematis siswa, kemampuan menyatakan ide matematika ke dalam simbol matematika begitu juga dengan perhitungannya dalam kategori baik.

Pada penelitian ini, peneliti melihat pada kelas yang diajar dengan model pembelajaran kooperatif tipe TTW terjadi diskusi kelompok yang bertanggung jawab atas permasalahan yang diberikan dan siswa mampu mengajarkan solusi dari permasalahan yang ada kepada anggota dalam kelompoknya. Siswa dapat mengumpulkan dan mengembangkan ideide melalui percakapan terstruktur dengan teman sekelompoknya.

Pada kelas TTW, karakter siswa lebih aktif dibandingkan kelas TPS. Siswa mudah mengungkapkan apa yang belum mereka pahami sehingga guru lebih mudah memantau perkembangan proses belajar siswa. Tahap write ini juga membantu siswa memahami kembali apa yang telah mereka dapatkan pada tahap sebelumnya, karena dengan menuliskan kembali apa yang telah mereka pelajari akan membantu siswa dalam memahami materi tersebut.

Teori belajar yang mendasari pembelajaran dengan strategi Think Talk Write antara lain adalah teori belajar penemuan dan konstruktivisme (Ansari, 2016:63). Pendekatan mengajar dari teori belajar ini dikenal dengan nama Discovery. Pendekatan ini menegaskan bahwa siswa belajar bukan untuk memperoleh kumpulan pengetahuan belaka, tetapi dengan adanya belajar siswa memperoleh kesempatan untuk berpikir dan berpartisipasi dalam memperoleh pengetahuan. Artinya, pembelajaran ini lebih menekankan proses daripada produk (Ansari, 2016:64).

Teori konstruktivisme menegaskan bahwa, pengetahuan tidak dapat dipindahkan begitu saja dari pikiran guru ke pikiran siswa. Ini berarti, siswa itu

Nova Alwi Sihombing, Amin Fauzi. Perbedaan Kemampuan Komunikasi Matematis Siswa yang Diajar dengan Menggunakan Model Pembelajaran Kooperatif Tipe Think Pair Share dengan Tipe Think Talk Write pada Materi Kubus dan Balok di Kelas VIII SMPN 27 Medan. Jurnal Inspiratif, Vol. 3 No. 2 Agustus 2017 
sendiri harus aktif secara mental membangun struktur pengetahuan berdasarkan perkembangan tahap berpikirnya (Ansari, 2016:68).

Berdasarkan penelitian, penyebab siswa yang diajar dengan model pembelajaran kooperatif tipe TPS lebih rendah daripada siswa yang diajar dengan model pembelajaran kooperatif tipe TTW yaitu pada kelas TPS siswa kurang aktif dalam proses pembelajaran. Saat tahap diskusi berlangsung banyak dari pasanganpasangan diskusi mengalami kesulitan dalam menemukan sendiri konsep yang diharapkan. Pada kelas TPS membutuhkan perhatian yang lebih besar dari peneliti dikarenakan banyaknya kelompok yang terbentuk dan terjadi keributan saat berdiskusi dengan teman semejanya, hal ini berdampak pada waktu belajar yang kurang maksimal mengakibatkan guru kurang memperhatikan apakan konsep yang dibangun siswa pada tahap share sudah tepat.

Dari kedua model pembelajaran yang diterapkan dapat disimpulkan ada beberapa kelemahan-kelemahan yang ditemukan dalam penelitian ini yaitu : kelemahan siswa dalam membangun konsep secara mandiri karena apabila konsep tidak siswa pahami dengan baik maka siswa akan kesulitan untuk memecahkan masalah yang diberikan, lingkungan kelas yang tidak mendukung seperti adanya beberapa siswa yang sering membuat keributan karena sulit memahami pelajaran sehingga membuat kondisi kelas menjadi tidak kondusif, dan diperlukan waktu yang cukup banyak untuk melakukan kegiatan pembelajaran sedangkan alokasi waktu yang tersedia dalam kurikulum sangat terbatas.

Dengan demikian peneliti akan memperbaiki kelemahan peneliti dalam penelitian selanjutnya sehingga dapat memperoleh hasil yang lebih baik lagi.

\section{Kesimpulan}

Berdasarkan hasil penelitian dan analisis data yang telah diuraikan pada bab sebelumnya, maka peneliti menarik kesimpulan sebagai berikut kemampuan komunikasi matematis siswa yang diajar dengan menggunakan model pembelajaran kooperatif tipe Think Talk Write (TTW) lebih tinggi daripada kemampuan komunikasi matematis siswa yang diajar dengan menggunakan model pembelajaran kooperatif tipe Think Pair Share (TPS) di kelas VIII SMP N 27 Medan dengan ratarata hasil belajar siswa yang diajar dengan model pembelajaran kooperatif tipe Think Talk Write (TTW) adalah 70,3125 dan rata-rata hasil belajar siswa yang diajar dengan model pembelajaran kooperatif tipe Think Pair Share (TPS)adalah 64,6875 . Hal ini juga dibuktikan dari hasil pengujian hipotesis dimana $t_{\text {hitung }}<+t_{1-\alpha}$ yaitu $1,5857<+1,667$.

\section{DAFTAR PUSTAKA}

Abdurrahman, Mulyono, (2012), Pendidikan Bagi Anak Berkesulitan Belajar, Rieka Cipta, Jakarta.

Ansari, Bansu I., (2016), Komunsikasi Matematik, Strategi Berpikir dan Manajemen Belajar : Konsep dan Aplikasi, Penerbit Pena, Banda Aceh.

Darkasyi, Muhammad, (2014), Quantum Learning, Jurnal Didaktik Matematika, Vol. 1 No. 1, ISSN: 2355-4185, hal 21-34.

Ikashaum, Fertilia, (2014), Perbandingan Kemampuan Representasi Matematis Siswa Antara Model Pembelajaran TTW dan TPS, http://jurnal.fkip.unila.ac.id/index.ph p/MTK/article/view/4787 (Diakses 11 Januari 2017).

Jamaluddin, Muhammad, (2013), Kemampuan Komunikasi Matematika Siswa Dalam Pembelajaran Penemuan Terbimbing Pada Materi Teorema Pythagoras, Vol. 2 No. 1, hal 4,

Nova Alwi Sihombing, Amin Fauzi. Perbedaan Kemampuan Komunikasi Matematis Siswa yang Diajar dengan Menggunakan Model Pembelajaran Kooperatif Tipe Think Pair Share dengan Tipe Think Talk Write pada Materi Kubus dan Balok di Kelas VIII SMPN 27 Medan. Jurnal Inspiratif, Vol. 3 No. 2 Agustus 2017 
http://jurnalmahasiswa.unesa.ac.id/i ndex.php/mathedunesa/article/view/ 1222/2396 (Diakses 6 Maret 2017)

Nartani, Indah, (2015), Communication in Mathematics Contextual, Intenational Journal of Innovation and Research in Educational Sciences Vol. 2 No. 4, ISSN: 23495219, hal 284-287.

Salam, Reskiwati, (2014), Efektivitas Penggunaan Model Pembelajaran Kooperatif Tipe Think Pair Share (TPS) Untuk Meningkatkan Kepercayaan Diri dan Komunikasi Matematis Siswa SMA N 9 Makassar, Jurnal Nalar Pendidikan Vol. 2 No. 2, ISSN: 2339-0794, hal 230-236.

Shoimin, Aris, (2016), 68 Model Pembelajaran Inovatif Dalam Kurikulum 2013, Penerbit Ar-Ruzz Media, Yogyakarta.

Suhaedi, Didi, (2012), Peningkatan Kemampuan Komunikasi Matematis Siswa SMP Melalui Pendekatan Pendidikan Matematika Realistik, Makalah dipresentasikan dalam
Seminar Nasional Matematika dan Pendidikan Matematika, Yogyakarta, FMIPA UNY, 10 Desember 2012, ISBN: 978-97916353-8-7, hal 191-202.

Surya, E. (2010). Visual Thinking Dalam Memaksimalkan Pembelajaran Matematika Siswa Dapat Membangun Karakter Bangsa. Jurnal Abmas UPI Bandung, Vol. 10 No. 10 Oktober 2010.

Susanto, Herry Agus, (2015), Improving Student's Activity in Mathematics Communication Trough Metacognitive Learning Approach Based on Lesson Study, International Journal of Education and Research, Vol. 3 No. 2, hal 169180.

Trianto, (2009), Mendesain Model Pembelajaran Inovatif-Progresif: Konsep, Landasan, dan Implementasinya pada Kurikulum Tingkat Satuan Pendidikan (KTSP), Kencana Prenada Media Group, Jakarta.

Nova Alwi Sihombing, Amin Fauzi. Perbedaan Kemampuan Komunikasi Matematis Siswa yang Diajar dengan Menggunakan Model Pembelajaran Kooperatif Tipe Think Pair Share dengan Tipe Think Talk Write pada Materi Kubus dan Balok di Kelas VIII SMPN 27 Medan. Jurnal Inspiratif, Vol. 3 No. 2 Agustus 2017 